\title{
DOI 10.26886/2414-634X.1(45)2021.3
}

\section{UDC 657.1.012.1:336.74}

\author{
ANALYTICAL TOOLS FOR EVALUATION OF ECONOMIC \\ ENTITIES IN THE CONDITIONS OF BUSINESS DIGITALIZATION \\ Valentyna Panasyuk, Doctor of Economic, Professor, \\ https://orcid.org/0000-0002-5133-6431 \\ e-mail: Tina.panasjuk@gmail.com \\ Vadim Schuchmann, student \\ Western Ukrainian National University, Ukraine, Ternopil
}

The article, based on literature sources, identifies approaches to the formation of a set of indicators for evaluating the effectiveness of economic entities in terms of business digitalization: traditional and cost-oriented.

Within the framework of the traditional approach application, on the basis of financial results the expediency of application of the well-known indicators is proved.

Characteristics of «DuPont» factor model application in the conditions of digitalization of entities' activity are stressed, emphasis is placed on the need to structure sales revenue by separate operating segments, make changes in costs, asset structure, structure of funding sources through the use of various crowdfunding models.

Within the cost-oriented approach, the need to maintain the priority of maximizing value for business is justified, based on which the features of the indicators system to assess its effectiveness in connection with the introduction and dissemination of digital technologies are considered.

Keywords: digitalization, digital economy, digital business, digital assets, profit, profitability, factor model «DuPont», crowdfunding, costoriented indicators, economic value added, monetary value added, market value added, shareholder value added 
Панасюк В. М., доктор економічних наук, профресор; Шухманн В. А., студент, Аналітичний інструментарій оцінювання економічних суб'єктів в умовах цифровізації бізнесу / Західноукраїнський національний університет, Україна, Тернопіль

У статті на основі літературних джерел виокремлено підходи до формування сукупності показників оцінювання результативності діяльності економічних суб'єктів за умов цифровізації бізнесу: традиційний та вартісно-орієнтований. У межах застосування традиційного підходу обгрунтована доцільність застосування загальновідомих показників, сфрормованих на підставі фрінансових результатів. Виокремлено особливості застосування факторної моделі «DuPont» в умовах цифровізації діяльності суб'єктів, акцентовано на потребі структурування виручки від продаж за окремими операційними сегментами, внесення змін у склад витрат, структуру активів, структуру джерел фрінансування за рахунок використання різних моделей краудфрандингу. У межах вартісноорієнтованого підходу обгрунтована необхідність збереження пріоритету максимізації вартості для бізнесу, на підставі чого розглянуто особливості застосування системи показників для оцінювання його результативності у зв'язку із впровадженням та розповсюдженням цифррових технологій.

Ключові слова: цифровізація, цифррова економіка, цифроовий бізнес, цифрові активи, прибуток, рентабельність, фракторна модель «DuPont», краудфрандіне, вартісно-орієнтовані показники, економічна додана вартість, грошова додана вартість, ринкова додана вартість, акціонерна додана вартість

Панасюк В. М., доктор экономических наук, профрессор; Шухманн B. А., студент, Аналитический инструментарий оценки 
экономических субъектов в условиях цифровизации бизнеса / Западноукраинский национальный университет, Украина, Тернополь

В статье на основе литературных источников выделены подходы к фрормированию совокупности показателей оценки результативности деятельности экономических субъектов в условиях цифровизации бизнеса: традиционный и ценностноориентированный. В рамках применения традиционного подхода обоснована целесообразность применения общеизвестных показателей, сфрормированных на основании фринансовых результатов. Выделены особенности применения фракторной модели «DuPont» в условиях цифровизации деятельности субъектов, акцентировано на необходимости структурирования выручки от продаж по отдельным операционным сегментам, внесение изменений в состав расходов, структуру активов, структуру источников фринансирования за счет использования различных моделей краудфрандинга. В рамках ценностноориентированного подхода обоснована необходимость сохранения приоритета максимизации стоимости для цифрового бизнеса, на основании чего рассмотрены особенности применения системы показателей для оценки его результативности в связи с использованием и распространением цифровых технологий.

Ключевые слова: цифровизация, цифровая экономика, цифровой бизнес, цифрровые активы, прибыль, рентабельность, фракторная модель «DuPont», краудфрандине, ценностно-ориентированные показатели, экономическая добавленная стоимость, денежная добавленная стоимость, рыночная добавленная стоимость, акционерная добавленная стоимость 
Постановка проблеми. Для економічних суб’єктів, які прагнуть відповідати актуальним технологічним і технічним тенденціям нагальною потребою стало впровадження та розвиток інформаційнокомунікаційних технологій для підвищення ефрективності своєї діяльності. Розвиток цифрових технологій призводить до фрормування абсолютно нового сегмента економіки, який нині знаходиться на етапі становлення. Однак, вже зараз існують економічні суб'єкти, бізнесмоделі, яких повністю реалізовані у цифровому середовищі (компанії Uber, Facebook, онлайн банк-Monobank та ін.) та економічні суб'єкти, які впроваджують цифрові технології для вдосконалення своєї діяльності. Цифровізація суспільства і економіки держави вимагає від них адаптації до нових умов ведення бізнесу, модифрікації і розвитку аналітичного інструментарію як для оцінювання результатів діяльності, так і для обґрунтування управлінських рішень.

\section{Аналіз останніх досліджень і публікацій Дослідженню} фрункціонування економічних суб'єктів, потреб їх розвитку та ведення обліку за умов цифровізації діяльності присвячені роботи таких вітчизняних та зарубіжних науковців як: Г. Карчева, Р. Лернатович, В. Кавецький, С. Веретюк, В. Пілінський, Бруханський Р. , Спільник І. , Палюх М., Б. Гейтс, О. Вільямсон, С.Вінтер, М. Дженсен, А. Девіс, Дж. Зіммерманн, У. Меклінг, Б. Нейлбафрф, Р.Нельсон, Е. Петерс, К. Прахалад, Г. Саймон, С. Фелпс та ін.

Теоретичні і методичні аспекти використання моделей вартісноорієнтованих показників для оцінювання ефективності ведення бізнесу розглядали Р. Брейлі, Д.Л. Волков, І.В.Івашковська, А.Н. Козирєв, Т.Коупленд, С. Майєрс, Дж.Муррін, В. Петті, А. Раппапорт , Д. Россі, Дж. Беннет Стюарт, О.І. Давидов, Т. В Момот, І. Й Яремко та ін.

Постановка завдання. Незважаючи на важливість одержаних результатів, враховуючи постійне удосконалення теоретичних аспектів 
аналізу ефрективності ведення бізнесу, виникає потреба в удосконаленні методичного забезпечення процесу оцінювання результатів діяльності економічних суб'єктів за умов цифровізації їх діяльності. Тому цільовим завданням дослідження є систематизація показників, які будуть виступати як критеріальні для оцінювання діяльності таких суб'єктів.

Виклад основного матеріалу дослідження. В цифровій адженді України (план розвитку України до 2030 р.) визначено, що цифровізація $€$ перетворенням наявних аналогових (іноді електронних) продуктів, процесів та бізнес-моделей організації, в основі якої лежить ефективне використання цифрових технологій [14] У даній адженді цифровізацію визнано механізмом економічного зростання завдяки здатності технологій позитивно впливати на ефективність, результативність, вартість та якість економічної, громадської та особистої діяльності. Особливості цифровізації економіки, можливості та загрози для ефрективного фрункціонування економічних суб'єктів розглянуто у працях $[7 ; 12 ; 15]$

Незважаючи на суттєвий вплив цифрової економіки на бізнес важливими вимірником підприємницького успіху залишаються фрінансові результати: валовий прибуток, операційний прибуток, EBIT (Earning before Interests and Taxes - прибуток до виплати процентів і податків), прибуток до оподаткування, NOPAT (Net OperationProfit after Taxes - чистий операційний прибуток після оподаткування), чистий прибуток та розраховані на їх підставі показники рентабельності.

3 огляду на специфрічність діяльності економічного суб'єкта через створення спеціального інформаційно-комунікаційного ресурсу та певної цифрової платфрорми як носія бізнес-моделі, базисом зростання економічного потенціалу і фрормування конкурентних переваг є валовий прибуток як прибуток від основної діяльності. При цьому важливим $є$ 
оцінювання динаміки доходів і витрат окремих сегментів і в подальшому оцінка їх результативності 3 використанням показників рентабельності.

Розрахована на підставі чистого прибутку фрормула рентабельності власного капіталу шляхом деталізації спеціалістами американської компанії «DuPon» на показники-множники перетворилася на фракторну модель, яка дозволяє оцінити здатність підприємства генерувати прибуток (рис. 1).

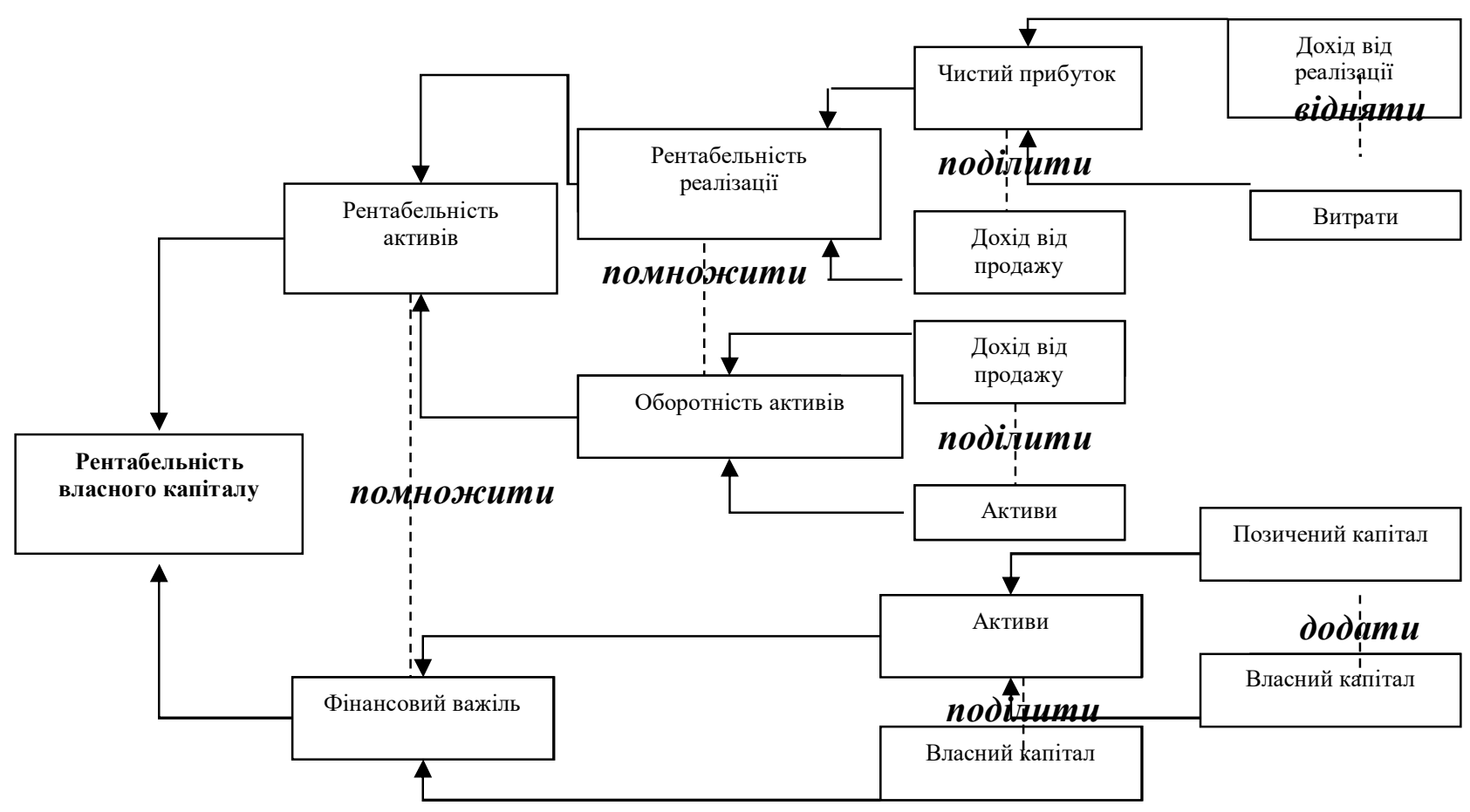

Рис. 1. Взаємозв'язок показників у моделі американської фрірми «DuPont»

Джерело: розроблено автором на підставі аналізу джерел [1; 13]

Використання даної моделі на практиці в умовах цифровізації діяльності вимагає врахування деяких особливостей. 3 огляду на географічну необмеженість ринку збуту економічних суб’єктів, перш за все, важливо дохід від продажу деталізувати за окремими операційними сегментами для оцінювання динаміки і фрормування висновку про доцільність існування сегментів у майбутньому. Потребує 
коригування і склад витрат економічних суб'єктів, врахування витрат на створення та ведення web-сайту, фрункціонування цифрової платформи, генерування, обробку, зберігання інформаційних даних, антивірусне обслуговування, доступ до хмарних технологій тощо. Шляхом зіставлення з доходом від продажу можна оцінювати окупність таких витрат.

Цифровизація діяльності вносить істотні зміни у структуру активів економічних суб'єктів. У ній будуть переважати необоротні активи, а саме довгострокові фінансові інвестиції та нематеріальні активи, крім того можлива поява нових видів останніх.

Наявність довгострокових фрінансових інвестицій пов'язано 3 інноваційністю цифрового бізнесу. Такі економічні суб’єкти досить часто або самі стають об'єктом для купівлі продажу, або активно розвиваються через поглинання або придбання інших. Це дозволяє збільшувати виручку від продажу за рахунок появи нових послуг та цифрових сервісів, росту клієнтської бази і посилення лояльності існуючої. Витрати на дослідження, фрормування і використання інтелектуального капіталу, просування продукції на ринку у вітчизняному фінансовому обліку не капіталізуються, а визнаються витратами періоду, зменшуючи прибуток підприємства. Оскільки такі витрати мають особливе значення для цифрового бізнесу, то їх треба розглядати як довгострокові інвестиції у розвиток бізнесу. Вказані витрати хоч і зменшуються поточний прибуток підприємства, однак сприяють його росту у майбутньому.

Значна частка нематеріальних активів у вигляді програмного забезпечення, бази даних, програмних продуктів та інших видів інтелектуальної власності пояснюється відсутністю потреби у створенні матеріальної бази бізнесу. Варто зазначити, що у структурі активів фінансової звітності відповідно до облікових стандартів, не 
відображаються, так звані, еквіваленти капіталу - репутація компанії, лояльність клієнтів, завантаженість цифрової платформи і т.д. Даний фракт зумовлює суттєву розбіжність між балансовою і ринковою вартістю активів суб'єктів цифрового бізнесу. Ефективне функціонування цих суб'єктів вимагає розроблення переліку та порядку відображення у балансі «цифрових активів».

Співвідношення між позиченим та власним капіталом $\epsilon$ відображенням структури капіталу економічного суб'єкта і характеризує його фрінансову стійкість, а не ефективність діяльності. На джерела фрормування капіталу впливає специфічність цифрового бізнесу: його суб'єкти позбавлені територіальної прив'язки, за винятком статусу резидента конкретної країни і, відповідно, обов'язків платника податків. Ïх капітал може мати як традиційне походження за рахунок акцій, облігацій, так і здійснювати 3 використанням різних моделей краудфандингу (колективного фрінансування). Перевагою краудфандингу $€$ можливість отримувати фрінансування без участі банків, венчурних фондів та бірж. Існують кілька моделей краудфандинга: без винагороди спонсору, фактично його пожертва; 3 нефрінансовою винагородою (подяка, згадка у реалізованому товарі тощо); 3 фрінансовою винагородою, так, званий краудінвестінг (передбачає отримання інвестором відсотку з доходів).

Однією із моделей краудфандингу є ICO (Initial coin offering), яка пов'язані з технологією блокчейн і передбачає залучення капіталу у вигляді емісії та продажу інвесторам нових криптовалют. Їх власники отримують право на участь в майбутніх прибутках суб'єкта або право на отримання послуг або товарів.

Моніторинг рівня фрінансового левериджу дозволяє управляти фрінансовою стійкістю на підставі оцінювання і зниження фрінансових та операційних ризиків шляхом перегляду ринкових операційних сегментів 
та відмови від реалізації певних проектів. При внесенні будь-яких коригувань повинні залишатися незмінними класичні співвідношення між основними показниками діяльності, які називають «золотим правилом економіки підприємства», а саме: темп зростання чистого прибутку має перевищувати темп зростання виручки від продажу; темп зростання виручки від продажу має перевищувати темп зростання активів. Така залежність свідчить про зниження витрат, ріст економічного потенціалу та ефективне використання ресурсів економічного суб'єкта.

Одним із показників для оцінювання діяльності економічних суб'єктів є залишковий дохід (RI - Residual Income). При його визначенні від чистого операційного прибутку віднімають суму витрат, пов'язаних із залученням інвестованого капіталу [9]:

$$
R I_{t}=N O P A T_{t}-W A C C_{t} \cdot \text { Capital Invested }{ }_{t-1},
$$

де $R l_{t}$ - залишковий дохід в момент $t$;

NOPAT $T_{t}$ - чистий операційний прибуток після вирахування податків до сплати відсотків у момент $t$;

Capital Invested $t-1$ - сукупний капітал, інвестований у підприємство на момент $t-1$;

$W A C C_{t}$ - середньозважена ціна інвестованого капіталу у момент $t$.

Як свідчить розрахунок, результативність бізнес зростає лише за умови перевищення прибутку над сумою витрат на залучення капіталу. При цьому економічний суб'єкт виконує свої зобов'язання перед інвесторами. Даний показник $є$ нескладним у розрахунку, може бути деталізований на систему показників-факторів та доведений до різних рівнів управління.

На початку 90-х минулого століття у міжнародній практиці отримала широке розповсюдження концепція менеджменту, яку можна 
визначити як управління за вартістю підприємства (Value-Based Management, VBM). Ï̈̈ сутність полягає у прикладанні зусиль управлінського персоналу на досягнення основної мети функціонування економічного суб'єкта - росту його вартості. Творці концепції зазначають, що збільшення фрінансових результатів за рахунок росту доходу та зменшення витрат має певну межу, а от зростання вартості меж немає. У зв'язку з цим низка відомих консалтингових фрірм (Stern Stewart\& Company, LEK/Arlca's, Boston Consulting Group та ін.) пропонує для оцінювання діяльності економічних суб'єктів різні моделі вартісно-орієнтованих показників. Серед них найбільш розповсюдженими є: економічна додана вартість (Economic Value Added, EVA), грошова додана вартість (Cash Value Added, CVA), ринкова додана вартість (Market Value Added, MVA), акціонерна додана вартість (Shareholder Value Added, SVA), TBR (Total Business Return - сукупна рентабельність бізнесу), показник прибутковості інвестицій на основі потоку грошових коштів (Cash Flow Return on Investment, CFROI). Всі інші фрінансові і нефрінансові показники розглядаються як фрактори фрормування вартості. Вітчизняним науковцями також пропонується їх використання у аналітичній практиці.

Серед перерахованих моделей найбільш відомою $є$ модель «економічної доданої вартості» (EVA), яка має такий вигляд [18]:

$$
E V A_{t}=\left(N O P A T_{t}+A d_{o p}\right)-W A C C_{t} \cdot\left(\text { Capital Invested }_{t-1}+A D_{j c}\right)
$$

де $E V A_{t}$ - економічна додана вартість у момент $t$;

NOPAT (Net Operating Profit After Tax) - чистий операційний прибуток після виплати податку на прибуток до сплати відсотків;

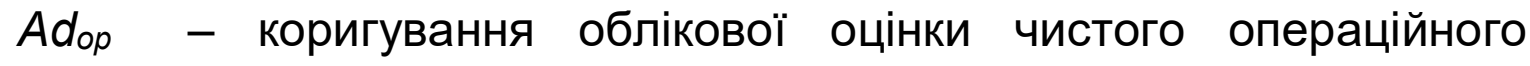
прибутку після виплати податку податків до сплати відсотків; 
WACC (Weighted Average Cost Of Capital) - середньозважена вартість капіталу;

(Capital Invested) - інвестований капітал;

$A D_{j c}$ - коригування облікової оцінки інвестованого капіталу.

Розробники концепції пропонують коригувати складові фрормули на, так звані, капітальні еквіваленти. Пропоновані коригування розглядаються на сторінках наукових джерел, однак їх перелік і досі залишається об'єктом наукової дискусії [5; 6; 13; 18]. Вважаємо, що їх значна кількість невиправдано збільшує трудомісткість розрахунку EVA, а тому $є$ економічно невигідною дією. Для суб'єктів цифрового бізнесу достатньо капіталізувати витрати на наукові дослідження і розробки, інформаційну безпеку, амортизацію ділової репутації, а також врахування дохід від оренди цифрових активів. Це актуально для формування лояльності і прив'язки клієнтів до певної цифрової платформи, розвитку бізнес-моделей за рахунок фоормування кількох сегментів цифрового бізнесу, що змінює сам механізм генерування прибутку.

3 огляду на різноманітність джерел фрінансування цифрового бізнесу, починаючи від класичної емісії акцій і облігацій, банківського кредитування і до емісії криптовалюти власної цифрової платформи, змінюються уявлення про інвестований капітал і його структуру, а отже і підхід до оцінювання його вартості.

Середньозважену вартість капіталу (WACC - Weighted Average Cost of Capital) розраховують за фрормулою:

$$
W A C C=K_{s} \cdot W_{s}+K_{d} \cdot W_{d}
$$

де WACC - середньозважена вартість капіталу (\%);

$\mathrm{K}_{\mathrm{s}}$ - вартість власного капіталу (\%);

$\mathrm{W}_{\mathrm{s}}$ - частка власного капіталу, виражена десятковим дробом;

$\mathrm{K}_{d}$ - вартість позикового капіталу (\%); 
Wd - частка позикового капіталу, виражена десятковим дробом.

Використання цієї стандартної фрормули суб'єктами цифрового бізнесу може бути ускладненим після емісії криптовалюти власною цифровою платформою, адже може призначатися для внутрівідомчих розрахунків і не мати ринкової оцінки.

Незважаючи на те, що розрахунок економічної доданої вартості $€$ дещо трудомісткий, однак, її можна деталізувати на систему показників-фракторів та довести до різних рівнів управління.

Ринкова додана вартість (MVA) відображає різницю між сумою засобів, яку вклали власники у бізнес при його створенні, і сумою, яку вони б виручили, продавши його. ІІї розраховують по різному: як приріст лише власного капіталу компанії; як різницю між ринковою вартістю компанії і вартістю інвестованого у неї капіталу; як дисконтований потік залишкового прибутку [5]. При використання MVA суб'єктами цифрового бізнесу необхідно врахувати, що її можна розрахувати лише за бізнесом в цілому, а не за окремими операційними сегментами, а ще вона фоормється під впливом об'єктивних факторів, які не залежать від менеджменту компанії.

CVA (Cash Value Added) грощова додана вартість $є$ схожою до показника EVA, але замість чистого операційного прибутку у розрахунку використовують чистий грошовий потік від операційної діяльності [16]:

$$
C V A_{t}=F C F_{t}-N A_{o} \cdot W A C C_{t},
$$

де CVA - грошова додана вартість у момент часу $t$;

$F C F_{t}$ - чистий грошовий потік до виплати процентних платежів у момент часу $t$;

$N A_{\circ}$ - чисті активи за первісною вартістю;

WACC - середньозважена вартість інвестованого капіталу. 
Чистий грошовий потік пропонується розраховувати непрямим методом збільшивши чистий операційний прибуток на бухгалтерську, і, зменшивши на економічну амортизацію [16]:

$$
F C F_{t}=E B I_{t}+D e p_{t}-E D_{t}
$$

де $E B I_{t}$ - чистий операційний прибуток до сплати податків і відсотків;

Dep $t$ - сума нарахованої амортизації за період $\mathrm{t}$;

$E D_{t}$ - сума економічної амортизації за період $\mathrm{t}$.

Труднощі використання даного показника, пов'язані із неоднозначністю обліку так званих, невідчутних, незареєстрованих активів, які відображають ділову репутацію, організаційну культуру, інтелектуальний капітал тощо. Це не дозволяє об'єктивно оцінити результативність бізнесу. А ще - у визначенні економічної амортизації. Бухгалтерська амортизація зменшує прибуток економічного суб'єкта за рахунок розподілу інвестицій в основні засоби і включення їх у собівартість виготовленої продукції, виконаних робіт, наданих послуг. Економічну амортизацію відображає обсяг інвестицій, яким можна відшкодувати первісну вартість основних засобів, вклавши їх у альтернативні проекти під відсоток рівний ставці середньозважених витрат на капітал. У [16] економічну амортизацію пропонують визначати за фрормулою:

$$
E D_{t}=\frac{G F A_{t} \cdot W A C C}{(1+W A C C)^{n}-1}
$$

де $G F A_{t}-$ первісна вартість основних засобів у період $t$;

$n$ - строк корисного використання основних засобів.

Перевагою CVA є те, що його можна використати для оцінювання конкретного операційного сегмента діяльності цифровізованої діяльності, доцільності здійснення стратегічних інвестицій.

Додана вартість акціонерного капіталу (SVA) відображає приріст вартості акціонерного капіталу, який сформовано за рахунок майбутніх 
інвестицій, у порівнянні з вартістю акціонерного капіталу, яка створена минулими інвестиціями, тобто балансовою вартістю акціонерного капіталу. Даний показник складний у використанні, бо передбачає визначення грошового потоку від поточних і майбутніх інвестицій. Проведення ретроспективного аналізу вартості акціонерного капіталу при визначенні SVA дозволяє встановити фрактори іï фрормування i, відповідно, результативність діяльності цифрового бізнесу на підставі таких показників як: дохід від реалізації, валовий прибуток, грошовий потік від операційної діяльності і т.д. При прогнозуванні вартості акціонерного капіталу потрібно:

- встановити сукупність активів, які будуть брати участь у цифрровому бізнесі;

- встановити необхідний розмір необоротних і оборотних активів;

- розробити варіанти джерел залучення капіталу та змоделювати їх структуру 3 урахуванням зовнішніх і внутрішніх ризиків;

- спрогнозувати вартість власного та позиченого капіталів;

- оптимізувати надходження і видатки від операційної діяльності;

- встановити фрактори фрормування середньозваженої вартості капіталу, на підставі оцінювання зовнішнього та середовища та фрінансового стану суб'єкта, розглянути можливості її мінімізації.

Дослідження проведені науковцями [4; 6] засвідчують, що використання тих чи інших показників оцінювання результативності бізнесу визначається життєвим циклом суб'єкта. На ранніх стадіях доречним $€$ використання традиційних фрінансових показників, моделі «DuPont».. Використання моделей вартісно-орієнтованих показників буде найбільш доцільним при входженні економічного суб'єкта у етап 
зрілості. Такий етап характеризується стійким зростанням прибутку та рентабельності, фрінансової стійкості та ділової активності.

\section{Висновки з проведеного дослідження.}

Дослідженням встановлено, що економічні суб'єкти за умов цифровізації діяльності реалізують нові бізнес моделі, фрормують цифрові активи та власне цифрове середовище. Рівень розповсюдженням цифрових та інфрормаційно-комунікаційних технологій у реальному секторі вітчизняної економіки не має всеохоплюючого характеру, тому відсутня потреба у формуванні принципово нових показників оцінювання їх діяльності. Обґрунтовано необхідність збереження пріоритету показників, які ґрунтуються на фрінансових результатах, а також застосування фракторної моделі ««DuPont» для економічних суб'єків, які знаходяться на ранніх етапах життєвого циклу. Їх використання на практиці в умовах цифровізації діяльності вимагає врахування деяких особливостей: структурування доходів та прибутку за окремими операційними сегментах, коригування витрат, внесення зміни у структуру активів, доповнення джерел фрормування капіталу за рахунок використання різних моделей краудфандинга

Використання моделей вартісно-орієнтованих показників для оцінювання діяльності економічних суб'єктів є виправданим на етапі зрілості бізнесу, який характеризується стійким зростанням прибутку та рентабельності, фрінансової стійкості та ділової активності. Потреба у максимізації вартості для цифрового бізнесу дозволило сформувати логічну послідовність показників від залишкового доходу до показників, які ґрунтуються на економічному прибутку (економічна додана вартість, ринкова додана вартість) та грошовому потоці (грошова додана вартість, акціонерна додана вартість). Визначено особливості їх використання економічними суб'єктами, що функціонують в умовах 
розвитку цифровізації і виявляють потребу в адекватному аналітичному інструментарії оцінки результативності їх діяльності.

Розрахунок вартісно-орієнтованих показників для оцінювання результативності цифрового бізнесу вимагають визначення середньозваженої вартості інвестованого капіталу. Використання різних джерел фрінансування цифрового бізнесу, починаючи від класичної емісії акцій і облігацій, банківського кредитування і до емісії криптовалюти власної цифрової платформи, змінюються уявлення про інвестований капітал і його структуру, а отже і підхід до оцінювання його вартості. Формування підходів оцінювання вартості економічного суб'єкта за умов цифровізації діяльності і є основними напрямами, за якими мають здійснюватися подальші наукові дослідження з даної проблематики.

\section{תimepamypa:}

1. Бланк И.А. (2002). Управление денежными потоками. К. Ника-Центр «Эльга». 736 с.

2. Бруханський Р.Ф., Спільник І.В. Криптоактиви у системі бухгалтерського обліку та звітності. Проблеми економіки. Економічна статистика. Бухгалтерський облік та аудит. № 2 (40), 2019. С.145156. URL: https://doi.org/10.32983/2222-0712-2019-2-145-156 ( дата звернення 09.01.2021).

3. Спільник І.В., Палюх М.С. (2019). Бухгалтерський облік в умовах цифрової економіки. Інститут бухгалтерського обліку, контроль та аналіз в умовах глобалізації. Випуск 1-2. С. 83-96. URL: https://doi.org/10.35774/ibo2019.01.083 ( дата звернення 19.01.2021).

4. Волков Д.Л. Теория ценностно-ориентированного менеджмента: фринансовый и бухгалтерский аспекты: монография. СПб. Изд-во «Высшая школа менеджмента»; Издат. дом СПб. гос. ун-та, 2008. 320 C. 
URL: http://serbakov.narod.ru/olderfiles/3/VolkovDL_Teoriya_ccennostnoorient-43135.pdf ( дата звернення 19.01.2021)/

5. Давидов О.І. Моделі доданої вартості підприємств: економічний зміст та особливості побудови. Науковий вісник Міжнародного гуманітарного університету. С. 167-172.

6. Ивашковская И.В. Моделирование стоимости компании. Стратегическая ответственность совета директоров. М. Издатель. Инфрра-М, 2009. 430 с. (Серия «Научная мысль»).

7. Козырев А.Н. (2018). Цифровая экономика и цифровизация в историчесикой ретроспективе. Цифрровая экономика. №1 (1). URL: http://digital-economy.ru/images/easyblog_articles/317/DE-2018-01-01.pdf (дата звернення 08.01.2021).

8. Мельничук Г.С., Мамалига В.О. (2020). Цифровізація економіки: можливості та загрози для ефективного функціонування підприємств. Приазовський економічний вісник. Вип. 2 (19). С. 125-130. URL: http://pev.kpu.zp.ua/journals/2020/2_19_ukr/23.pdf ( дата звернення 08.01.2021).

9. Модильяни Р., М. Миллер. (2001). Сколько стоит фрирма? Теорема ММ. Изд. 2-е. М. Дело. 272 с.

10. Момот Т.В. (2006). Вартісно-орієнтоване корпоративне управління від теорії до практичного впровадження. Т.В. Момот. Харків. ХНАМГ, 380c.

11. Про схвалення Концепції розвитку цифрової економіки та суспільства України на 2018-2020 роки та затвердження плану заходів щодо ії реалізації. Розпорядження КМУ від 17 січня 2018 р. №о 67-р. Дата оновлення 09.09.2020. URL:

https://zakon.rada.gov.ua/laws/show/67-2018-\%D1\%80\#Text (дата звернення 06.01.2021). 
12. Руденко М.В. (2018). Цифровізація економіки: нові можливості та перспективи. Економіка та держава. № 11. С. 61-65. URL:http://www.economy.in.ua/pdf/11_2018/13.pdf (дата звернення 24.12.2020).

13. Серединська І.В., Серединська В.М. (2015). Особливості інтегрування систем вартісно-орієнтованого управління підприємствами; за заг. ред. Н.Б. Кирич. Тернопіль ФОП Паляниця В.А. 354c

14. Україна 2030Е - країна з розвинутою цифровою економікою. Цифрова адженда України», оцінки Ukrainian Institute for the Future. https://strategy.uifuture.org/kraina-z-rozvinutoyu-cifrovoyuekonomikoyu.html ( дата звернення 04.01.2021)

15. Яненкова І.Г. (2017). Цифрова трансформація промисловості України: ключові акценти Проблеми економіки. № 4. С. 179-184. URL: https://www.problecon.com/export_pdf/problems-of-economy-2017-4_0pages-179_184.pdf ( дата звернення 05.12.2020)

16. Ottoson E., Weissenrieder F. Cash Value Added - a New Method for Measuring Financial Performance. Social Science Research Network, Gothenburg University Working Paper. 1996. № 1996:1. URL: file://C:/Users/home/AppData/Local/Temp/SSRN-id58436.pdf (log in date 10.12.2020).

17. Russ R. Economic Value Added: Theory, Evidence, A Missing Link. Review of Business. 2001. Vol. 22. № 1. pp. $66-71$.

18. Stern E., Stewart S and Co China Adopts EVA: An Essential Step in the Great Leap Forward. Journal of Applied Corporate Finance. 2011. vol 23. №. 1. pp. 57-62.

URL:https://onlinelibrary.wiley.com/doi/epdf/10.1111/j.1745-

6622.2011.00314.x (log in date: 27.12.2020).

\section{References:}


1. Blank I.A. (2002) Upravlenie denezhnymi potokami. K. Nika-Centr «Jel'ga», $736 \mathrm{~s}$.

2. Brukhanskyi R.F., Spilnyk I.V. (2019) Kryptoaktyvy u systemi bukhhalterskoho obliku ta zvitnosti. Problemy ekonomiky. Ekonomichna statystyka. Bukhhalterskyi oblik ta audyt. № 2 (40),. S.145-156. URL: https://doi.org/10.32983/2222-0712-2019-2-145-156 (2021, January, 09).

3. Spilnyk I.V., Paliukh M.S. (2019) Bukhhalterskyi oblik v umovakh tsyfrovoi ekonomiky. Instytut bukhhalterskoho obliku, kontrol ta analiz $v$ umovakh hlobalizatsii. Vypusk 1-2. S. 83-96. URL: https://doi.org/10.35774/ibo2019.01.083 ( 2021, January, 19).

4. Volkov D.L. (2008) Teorija cennostno-orientirovannogo menedzhmenta: finansovyj i buhgalterskij aspekty: monografija. SPb.: Izdvo «Vysshaja shkola menedzhmenta»; Izdat. dom SPb. gos. un-ta, 320s. URL"http://serbakov.narod.ru/olderfiles/3/VolkovDL_Teoriya_ccennostnoorient-43135.pdf (2021, January,19)

5. Davydov O.I. (2018) Modeli dodanoi vartosti pidpryiemstv: ekonomichnyi zmist ta osoblyvosti pobudovy. Naukovyi visnyk Mizhnarodnoho humanitarnoho universytetu. S.167-172.

6. Ivashkovskaja I.V. (2009) Modelirovanie stoimosti kompanii. Strategicheskaja otvetstvennost' soveta direktorov.M. Izdatel'. Infra-M, 430 s. (Serija «Nauchnaja mysl'»).

7. Kozyrev A.N. (2018) Cifrovaja jekonomika i cifrovizacija v istorichesikoj retrospektive. Cifrovaja jekonomika. №1 (1). URL: http://digital-economy.ru/images/easyblog_articles/317/DE-2018-01-01.pdf (2021, January, 08).

8. Melnychuk H.S., Mamalyha V.O. (2020) Tsyfrovizatsiia ekonomiky: mozhlyvosti ta zahrozy dlia efektyvnoho funktsionuvannia pidpryiemstv. Pryazovskyi ekonomichnyi visnyk. Vyp. 2 (19). S. 125-130. URL: http://pev.kpu.zp.ua/journals/2020/2_19_ukr/23.pdf (2021, January, 08). 
9. Modil'jani P., M. Miller. (2001) Skol'ko stoit firma? Teorema MM. Izd. 2-e. M. Delo, 272 s.

10. Momot T.V. (2006) Vartisno-oriientovane korporatyvne upravlinnia vid teorii do praktychnoho vprovadzhennia. T.V. Momot. Kharkiv. KhNAMH, 380 s.

11. Pro skhvalennia Kontseptsii rozvytku tsyfrovoi ekonomiky ta suspilstva Ukrainy na 2018-2020 roky ta zatverdzhennia planu zakhodiv shchodo yii realizatsii. Rozporiadzhennia KMU vid 17 sichnia 2018 r. (Order of the Cabinet of Ministers) №o 67-r. Data onovlennia 09.09.2020. URL: https://zakon.rada.gov.ua/laws/show/67-2018-\%D1\%80\#Text (2021, January, 06).

12. Rudenko M.V. (2018) Tsyfrovizatsiia ekonomiky: novi mozhlyvosti ta perspektyvy. Ekonomika ta derzhava, № 11. S. 61-65. URL:http://www.economy.in.ua/pdf/11_2018/13.pdf (2020, December, 24).

13. Seredynska I.V., Seredynska V.M. (2015) Osoblyvosti intehruvannia system vartisno-oriientovanoho upravlinnia pidpryiemstvamy; za zah. red N. B.Kyrych. Ternopil FOP Palianytsia V.A., 354s

14. Ukraina 2030E - kraina z rozvynutoiu tsyfrovoiu ekonomikoiu. Tsyfrova adzhenda Ukrainy», otsinky Ukrainian Institute for the Future. https://strategy.uifuture.org/kraina-z-rozvinutoyu-cifrovoyuekonomikoyu.html (2021, January, 04).

15. lanenkova I. H. (2017) Tsyfrova transformatsiia promyslovosti Ukrainy: kliuchovi aktsenty Problemy ekonomiky. № 4. S. 179-184. URL: https://www.problecon.com/export_pdf/problems-of-economy-2017-4_0pages-179_184.pdf (2020, December, 05).

16. Ottoson E., Weissenrieder F. Cash (1996) Value Added - a New Method for Measuring Financial Performance. Social Science Research Network, Gothenburg University Working Paper. № 1996:1. URL: 
file://C:/Users/home/AppData/Local/Temp/SSRN-id58436.pdf (2020, December, 10).

17. Russ R. (2001) Economic Value Added: Theory, Evidence, A Missing Link. Review of Business. Vol. 22. № 1. pp. $66-71$.

18. Stern E., Stewart S and Co China Adopts EVA: (2011) An Essential Step in the Great Leap Forward. Journal of Applied Corporate Finance. vol 23. №. 1. pp. 57-62. URL:

https://onlinelibrary.wiley.com/doi/epdf/10.1111/j.1745-6622.2011.00314.x (2020, December, 27).

Citation: V. Panasyuk, V. Schuchmann (2021). ANALYTICAL TOOLS FOR EVALUATION OF ECONOMIC ENTITIES IN THE CONDITIONS OF BUSINESS DIGITALIZATION. New York. TK Meganom LLC. Innovative Solutions in Modern Science. 1(45). doi: 10.26886/2414-634X.1(45)2021.3

Copyright: V. Panasyuk, V. Schuchmann (C). 2021. This is an openaccess article distributed under the terms of the Creative Commons Attribution License (CC BY). The use, distribution or reproduction in other forums is permitted, provided the original author(s) or licensor are credited and that the original publication in this journal is cited, in accordance with accepted academic practice. No use, distribution or reproduction is permitted which does not comply with these terms. 